\title{
TMPRSS2 wt Allele
}

National Cancer Institute

\section{Source}

National Cancer Institute. TMPRSS2 wt Allele. NCI Thesaurus. Code C50377.

Human TMPRSS2 wild-type allele is located in the vicinity of $21 \mathrm{q} 22.3$ and is approximately

$51 \mathrm{~kb}$ in length. This allele, which encodes transmembrane protease, serine 2 protein, plays a role in G-protein-coupled-receptor activation. The TMPRSS2 gene is overexpressed in neoplastic prostate epithelium. It has also been shown to be translocated in prostate tumors wherein certain fusion genes are formed with other transcription factor genes. 